\title{
Tanggung Jawab Bank terhadap Simpanan Deposito Berjangka yang Tidak Tercatat dihubungkan dengan Perlindungan Hukum Nasabah menurut Undang-Undang Nomor 10 Tahun 1998 tentang Perbankan
}

\author{
Rosalia Alima Utami Rohaedi* \\ Prodi Ilmu Hukum, Fakultas Hukum, Universitas Islam Bandung, Indonesia. \\ *rosaliaalimaur@gmail.com
}

\begin{abstract}
Banking institutions have a role as supporting the economic life of a country and improve the living standards of the people and has the function of a financial intermediary (financial intermediary), which serves to raise and distribute funds to the community. Law No. 10 of 1998 on Banking there is a discussion about responsibility and legal protection of customers for deposits for the actions of bank employees. In raising these funds, customer trust Mega-Banks to deposit funds in the form of transaction deposits. In practice, YA as employees of a Mega Bank did not record such transactions to the banking system officially. As a result the customer can not dilute the deposit slip. Based on this, the problem in this research is formulated as follows: (1) How is the responsibility of the bank to the savings deposits of which are not recorded according to Law No. 10 of 1998 on Banking? (2) How legal protection for the customers of the savings deposits of which are not recorded according to Law No. 10 of 1998 on Banking?. Researchers using the method of approach used in this research is normative juridical, namely the methods of researching and studying the material-primary legal materials and secondary legal materials. As well as a descriptive analysis, which describes the laws and regulations that apply associated with the theories of law in the implementation of practices on the issue under study. The results of this study (1) the responsibility of the bank on transactions deposits time deposits which are not recorded that according to article 1365 of the civil Code, namely the employees of the bank have committed acts against the law and is obliged to replace the loss amounted to a loss of the customer arising out of his guilt. (2) The legal protection that can be received by the customer of the bank in terms of transaction deposits time deposits which are not recorded in the banking system is authorized by the employee of Bank Mega. Then the customer is entitled to get legal protection directly regulated in Article 29 paragraph (3) of the Banking Act that the bank is obliged to travel a ways that are not detrimental to the bank and the interests of the clients who entrust their funds to the bank. As well as the protection is not directly according to Article 29, paragraph 2 of Law No. 10 of 1998 on Banking which gives legal protection to depositors in the form of the implementation of the principle of prudence, as well as financial institutions are required to keep the security deposit.
\end{abstract}

Keywords: Banking, responsibility, protection of the law.

\begin{abstract}
Abstrak. Lembaga perbankan mempunyai peran sebagai menunjang kehidupan ekonomi suatu negara serta meningkatkan taraf hidup masyarakat dan mempunyai fungsi financial intermediary (lembaga perantara keuangan) yang berfungsi menghimpun dan menyalurkan dana kepada masyarakat. Undang-Undang Nomor 10 Tahun 1998 tentang Perbankan terdapat pembahasan tentang tanggung jawab serta perlindungan hukum nasabah mengenai simpanan atas tindakan pegawai bank. Dalam melakukan penghimpunan dana tersebut, nasabah mempercayai Bank Mega untuk menyimpan dana dalam bentuk transaksi deposito berjangka. Pada praktiknya, YA selaku pegawai Bank Mega tidak melakukan pencatatan transaksi tersebut kepada sistem perbankan secara resmi. Akibatnya nasabah tidak dapat mencairkan bilyet deposito. Berdasarkan hal tersebut, maka permasalahan dalam penelitian ini dirumuskan sebagai berikut: (1) Bagaimana tanggung jawab bank terhadap simpanan deposito berjangka yang tidak tercatat menurut Undang-Undang Nomor 10 Tahun 1998 tentang Perbankan? (2) Bagaimana perlindungan hukum bagi nasabah terhadap simpanan deposito berjangka yang tidak tercatat menurut Undang-Undang Nomor 10 Tahun 1998 tentang Perbankan?. Peneliti menggunakan metode pendekatan yang digunakan dalam penelitian ini adalah yuridis normative, yaitu metode yang meneliti dan mempelajari bahan-bahan hukum primer dan bahan hukum sekunder. Serta deskriptif analisis, yaitu menggambarkan peraturan perundang-undangan yang berlaku yang dikaitkan dengan teori-teori hukum dalam pelaksanaan praktik pada masalah yang diteliti. Hasil dari penelitian ini (1) Tanggung jawab bank atas transaksi simpanan deposito berjangka yang tidak tercatat yaitu menurut pasal 1365 KUHPerdata yaitu pegawai bank tersebut telah melakukan perbuatan melawan hukum dan wajib untuk mengganti kerugian sebesar kerugian nasabah yang timbul dari kesalahannya. (2) Perlindungan hukum yang dapat diterima nasabah bank dalam hal transaksi simpanan deposito berjangka yang tidak tercatat dalam sistem perbankan secara resmi oleh pegawai Bank Mega. Maka nasabah berhak mendapatkan perlindungan hukum langsung yang diatur pada Pasal 29 ayat (3) Undang-Undang Perbankan bahwa bank wajib menempuh cara-cara yang tidak merugikan bank dan kepentingan nasabah yang mempercayakan dananya kepada bank. Serta pelindungan tidak langsung menurut Pasal 29 ayat 2 Undang-Undang Nomor 10 Tahun 1998 tentang Perbankan yaitu memberikan perlindungan hukum pelaksanaan prinsip kehati-hatian, serta lembaga keuangan wajib menjaga keamanan simpanan.
\end{abstract}

Kata Kunci: Perbankan, tanggung jawab, perlindungan hukum. 


\section{A. Pendahuluan}

Lembaga perbankan memiliki peran yang sangat penting sebagai penunjang kehidupan ekonomi disuatu negara serta dapat meningkatkan taraf hidup masyarakat. Lembaga perbankan dapat juga disebut sebagai lembaga keuangan yang mempunyai fungsi sebagai financial intermediary (lembaga perantara keuangan) yang memiliki peran sebagai menghimpun dan menyalurkan dana kepada masyarakat. Hal tersebut sebagaimana diatur di Undang-Undang Nomor 10 Tahun 1998 tentang Perbankan. Maka dari itu bank memiliki kewajiban untuk menyediakan dana dengan cara yang baik serta melayani kepentingan masyarakat atas dana yang ada pada bank.

Pelayanan jasa bank terdiri atas penghimpunan dana dan menyalurkan dana. Maksud dari penghimpunan dana adalah bank dapat menghimpunan dana dari masyarakat dalam bentuk simpanan deposito. Pengertian deposito berjangka adalah jenis simpanan atau produk yang dikeluarkan oleh bank yang memiliki unsur jangka waktu (jatuh tempo) lebih panjang dan simpanan tersebut tidak dapat ditarik setiap saat. Kepemilikan simpanan deposito berjangka dapat dibuktikan oleh suatu surat yang dikenal dengan bilyet deposito.

Terdapat berbagai macam produk simpanan pada bank, nasabah memiliki alasan tersendiri untuk menyimpan dana pada bank agar tidak memiliki resiko kehilangan yang tinggi. Akan tetapi, banyak nasabah dirugikan oleh pihak bank. Kerugian tersebut ditimbulkan akibat dari kejahatan perbankan atau kelalaian dari pihak bank atau pegawai bank dalam menerapkan prinsip kehati-hatian. Dalam hal tersebut nasabah yang memiliki bilyet deposito, tetapi transaksinya tidak tercatat dalam sistem perbankan. Akibatnya bahwa nasabah yang menggunakan jasa perbankan tersebut tidak terdaftar sebagai nasabah simpanan dana deposito berjangka pada sistem yang ada di bank.

Berdasarkan latar belakang yang telah diuraikan, maka perumusan masalah dalam penelitian ini sebagai berikut:

"Bagaimana tanggung jawab bank terhadap simpanan deposito berjangka yang tidak tercatat menurut Undang-Undang Nomor 10 Tahun 1998 tentang Perbankan?"

"Bagaimana perlindungan hukum bagi nasabah terhadap simpanan deposito berjangka yang tidak tercatat menurut Undang-Undang Nomor 10 Tahun 1998 tentang Perbankan?"

\section{B. Landasan Teori}

Menurut Muhammad Djumhana, hukum perbankan adalah sebagai kumpulan peraturan hukum yang mengatur kegiatan lembaga keuangan bank yang meliputi segala aspek, dilihat dari segi esensi, dan eksistensinya, serta hubungannya dengan bidang kehidupan yang lain.

Menurut Pasal 1 angka 1 Undang-Undang Nomor 10 Tahun 1998 tentang Perbankan menjelaskan bahwa perbankan adalah segala sesuatu yang menyangkut tentang bank, mencakup kelembagaan, kegiatan usaha, serta cara dan proses dalam melaksanakan kegiatan usahanya. Menurut Kasmir secara sederhana bank dapat diartikan sebagai lembaga keuangan yang kegiatan utamanya adalah menghimpun dana dari masyarakat dan menyalurkan kembali dana tersebut ke masyarakat serta memberikan jasa bank lainnya.

Menurut ketentuan Pasal 1 angka 7 Undang-Undang Nomor 10 Tahun 1998 tentang Perbankan menjelaskan:

"Deposito adalah simpanan yang penarikannya hanya dapat dilakukan pada waktu tertentu berdasarkan perjanjian Nasabah Penyimpan dengan bank."

Menurut Artikel Finansial (2016) menyatakan deposito berjangka adalah produk bank sejenis tabungan, dimana uang yang disetorkan dalam deposito berjangka tidak boleh ditarik nasabah dan baru bisa dicairkan sesuai dengan tanggal jatuh temponya. Ada beberapa jangka waktu yang dapat dipilih, yaitu $1,3,6,12$, atau 24 bulan. Deposito tidak dapat ditarik sebelum tanggal jatuh tempo, bila hal tersebut terjadi akan dikenakan penalti.

KUHPerdata memperincikan kerugian (yang harus diganti) dalam tiga komponen sebagai berikut :

1. Biaya

2. Rugi.

3. Bunga 
Teori tanggung jawab hukum adalah teori yang mengkaji terkait tanggung jawab subjek hukum atas tindakan yang mengakibatkan perbuatan melawan hukum atau perbuatan pidana untuk menangung biaya atau kerugian atas kesalahannya maupun karena kealpaannya. Dalam teori tanggung jawab hukum menurut Hans Kelsen mengatakan bahwa seseorang dapat bertanggung jawab secara hukum atas suatu perbuatan tertentu atau bahwa dia memikul tanggung jawab hukum, subjek berarti bahwa dia dapat melakukan pertanggung jawaban atas suatu sanksi dalam hal perbuatan yang bertentangan. berikut:

Secara umum, prinsip-prinsip tanggung jawab dalam hukum dapat dibedakan sebagai

1. Prinsip tanggung jawab berdasarkan unsur kesalahan

Prinsip tanggung jawab berdasarkan unsur kesalahan (fault liability atau liability based on fault) adalah prinsip yang cukup umum berlaku dalam hukum pidana dan perdata. Dalam Kitab Undang-Undang Hukum Perdata, khususnya Pasal 1365, 1366, dan 1367, prinsip ini dipegang secara teguh.

Prinsip ini menyatakan, seseorang baru dapat dimintakan pertanggungjawabannya secara hukum jika ada unsur kesalahan yang dilakukannya. Yang dimaksud kesalahan adalah unsur yang bertentangan dengan hukum. Pengertian "hukum", tidak hanya bertentangan dengan undang-undang, tetapi juga kepatutan dan kesusilaan dalam masyarakat. Secara common sense, asas tanggung jawab ini dapat diterima karena adalah adil bagi orang yan berbuat salah untuk mengganti kerugian bagi pihak korban.

2. Prinsip praduga untuk selalu bertanggung jawab

Prinsip ini menyatakan, tergugat selalu dianggap bertanggung jawab (presumption of liability principle), sampai ia dapat membuktikan, ia tidak bersalah. Jadi, beban pembuktian ada pada si tergugat.

3. Prinsip praduga untuk tidak selalu bertanggung jawab

Prinsip ini adalah kebalikan dari prinsip kedua. Prinsip praduga untuk tidak selalu bertanggung jawab (presumption of nonliability principle) hanya dikenal dalam lingkup transaksi konsumen yang sangat terbatas, dan pembatasan demikian biasanya secara common sense dapat dibenarkan.

4. Prinsip tanggung jawab mutlak

Prinsip tanggung jawab mutlak (strict liability) sering diidentikkan dengan prinsip tanggung jawab absolut (absolute liability). Kendati demikian ada pula para ahli yang membedakan kedua terminology di atas. Ada pendapat yang mengatakan, strict liability adalah prinsip tanggung jawab yang menetapkan kesalahan tidak sebagai faktor yang menentukan.

Namun, ada pengecualian-pengecualian yang memungkinkan untuk dibebaskan dari tanggung jawab, misalnya keadaan force majure. Sebaliknya, absolute liability adalah prinsip tanggung jawab tanpa kesalahan dan tidak ada pengecualiannya.

5. Prinsip tanggung jawab dengan pembatasan

Prinsip tanggung jawab dengan pembatasan (limitation of liability principle) sangat disenangi oleh pelaku usaha untuk dicantumkan sebagai klausula eksonerasi dalam perjanjian standar yang dibuatnya. Faktanya, prinsip tanggung jawab ini sangat merugikan konsumen bila ditetapkan secara sepihak oleh pelaku usaha.

Pasal 1 ayat 3 Undang-Undang Dasar 1945 menyatakan bahwa Indonesia adalah negara hukum. Dengan demikian negara menjamin hak-hak hukum warga negaranya dengan memberikan perlindungan hukum dan perlindungan hukum akan menjadi hak bagi setiap warga negara.

Menurut Setiono, perlindungan hukum adalah tindakan atau upaya untuk melindungi masyarakat dari perbuatan sewenang-wenang oleh penguasa yang tidak sesuai dengan aturan hukum, untuk mewujudkan ketertiban dan ketentraman, sehingga memungkinkan manusia untuk menikmati martabatnya sebagai manusia.

Perlindungan hukum bagi nasabah tentu melindungi kepentingan dari nasabah penyimpan dan simpanannya yang disimpan disuatu bank tertentu terhadap suatu kerugian. 
Berkaitan dengan perlindungan hukum terhadap nasabah dibagi menjadi dua macam yaitu:

1. Perlindungan Tidak Langsung, Perlindungan hukum yang diberikan kepada nasabah penyimpan terhadap segala risiko kerugian yang timbul dari adanya suatu kebijakan atau timbul dari kegiatan usaha yang dilakukan oleh bank. Maka hal ini merupakan upaya dan tindakan pencegahan bersifat internal dari bank yang bersangkutan.

2. Perlindungan Langsung, Perlindungan ini diberikan kepada nasabah penyimpan dana secara langsung terhadap akan timbulnya risiko kerugian dari kegiatan usaha yang dilakukan oleh bank.

Perlindungan hukum terhadap nasabah ini dikemukakan oleh Marulak Pardede bahwa sistem perbankan di Indonesia terkait perlindungan nasabah penyimpan dapat dilakukan melalui dua cara yaitu:

1. Perlindungan secara implisit, Perlindungan ini dilakukan dengan cara pengawasan dan pembinaan bank yan efektif, dan dapat menghindarkan bank terhadap terjadinya kebangkrutan.

2. Perlindungan secara ekspisit, Perlindungan ini dilakukan melalui pembentukan suatu lembaga yang menjamin simpanan. Maka dari itu apabila bank mengalami kegagalan lembaga tersebut yang menjadi simpanan masyarakat.

\section{Hasil dan Pembahasan}

Tanggung jawab bank terhadap simpanan deposito berjangka yang tidak tercatat menurut Undang-Undang Nomor 10 Tahun 1998 tentang Perbankan.

Menurut Pasal 49 ayat 1b Undang-Undang Nomor 10 Tahun 1998 tentang Perbankan menjelaskan bahwa pegawai bank dilarang untuk tidak dilakukannya pencatatan dalam laporan transaksi atau rekening suatu bank. Pencatatan dalam laporan transaksi disini bertujuan agar nama nasabah tersebut terdaftar sebagai penyimpan dana dalam sistem perbankan dan agar adanya kecocokan dengan bilyet deposito yang sudah dikeluarkan oleh bank sebagai bukti kepemilikan depostio berjangka.

Untuk mengetahui tanggung jawab yang harus dilaksanakan oleh bank, maka tidak bisa terlepas dari hubungan hukum antara bank dengan nasabah. Tetapi di dalam Undang-Undang Nomor 10 Tahun 1998 tentang Perbankan tidak ada ketentuan yang spesifik mengenai hubungan hukum antara bank dengan nasabah. Namun, dari beberapa yang dapat disimpulkan bahwa hubungan hukum antara bank dengan nasabah diatur oleh perjanjian serta prinsip kepercayaan. Berdasarkan rumusan pasal 1 angka 17 Undang-Undang Perbankan memberi pengertian mengenai nasabah penyimpan yaitu "nasabah penyimpan adalah nasabah yang menempatkan dananya di bank dalam bentuk simpanan berdasarkan perjanjian bank dengan nasabah yang berangkutan".

Maka dengan hukum perjanjian diatur pada Buku III KUHPerdata yang memberikan kebebasan dalam membuat perjanjian asal tidak melanggar hukum dan mengenyampingkan itikad baik. Serta hubungan kepercayaan diatur dalam Pasal 29 ayat 4 Undang-Undang Nomor 10 Tahun 1998 tentang Perbankan. Hubungan kepercayaan tersebut terjadi karena nasabah sudah menganggap bank merupakan tempat yang aman dan terpercaya terhadap simpanan dana karena mempunyai kemampuan untuk dananya kembali apabila dibutuhkan sesuai dengan perjanjian deposito berjangka.

Untuk mengetahui tanggung jawab bank terhadap nasabah penyimpan dana deposito berjangka. Tindakan pegawai bank Bank Mega tersebut dapat dipertanggung jawaban menurut Pasal 49 ayat (2) huruf b Undang-Undang Perbankan menyatakan bahwa "Pegawai bank adalah pejabat bank yang mempunyai wewenang dan tanggung jawab tentang hal yang berkaitan dengan usaha bank yang bersangkutan". Adapula kode etik yang harus dipenuhi dan berlaku pada profesi bankir tetapi pegawai Bank Mega tersebut tidak mentaatinya yakni seorang bankir patuh dan taat pada ketentuan perundang-undangan dan peraturan yang berlaku, seorang bankir melakukan pencatatan yang benar mengenai segala transaksi yang bertalian dengan kegiatan banknya serta seorang bankir tidak melakukan perbuatan tercela yang dapat merugikan citra profesinya.

Menurut pasal 29 ayat 2 Undang-Undang Nomor 10 Tahun 1998 tentang Perbankan, 
bank wajib memelihara tingkat kesehatan bank sesuai dengan ketentuan kecukupan modal, kualitas asset, kualitas manajemen, likuiditas, rentabilitas, solvabilitas, dan aspek lain yang berhubungan dengan usaha bank, dan bank wajib melakukan kegiatan usaha dengan prinsip kehati-hatian. Dengan maksud dari pasal tersebut bahwa tindakan pegawai pada Bank Mega tidak memenuhi kriteria sebagai bank sehat, karena pegawai yang berkedudukan sebagai kepala cabang Bank Mega tersebut tidak begitu baik dalam hal tingkat kualitas manajemen terkait dalam menjalankan sistem operasional prosedur yang harus ditempuh dalam pembukaan transaksi simpanan dana deposito berjangka. Untuk mengatasi hal tersebut, adanya tanggung jawab dari pihak bank.

Tanggung jawab pegawai bank terhadap nasabah terkait dengan transaksi simpanan dana deposito yang tidak tercatat pada sistem perbankan Bank Mega termasuk pada prinsip tanggung jawab berdasarkan kesalahan (fault liability atau liability based on fault). Pada Kitab Undang-Undang Hukum Perdata terdapat pasal yang termasuk kedalam prinsip tanggung jawab berdasarkan kesalahan, yaitu pasal 1365, 1366, dan 1367. Prinsip ini menyatakan bahwa seseorang baru dapat diminta pertanggungjawaban secara hukum apabila adanya unsur kesalahan yang dilakukannya.

Serta menurut teori tanggung jawab dari Hans Kelsen memaparkan bahwa dalam kasus tersebut masuk kedalam pertanggung jawaban berdasarkan kesalahan yang memiki arti bahwa seorang individu dapat bertanggung jawab atas suatu tindakan pelanggaran yang dilakukannya karena alasan sengaja dan diperkirakan dengan tujuan untuk menimbulkan kerugian.

Tanggung jawab hukum perdata berdasarkan perbuatan melawan hukum dilandasi adanya hukum berupa hak dan kewajiban pegawai bank serta nasabah yang bersumber pada hukum. Menurut Pasal 1365 KUHPerdata, adanya empat unsur pokok yang harus terpenuhi yaitu :

1. Adanya perbuatan;

2. Adanya unsur kesalahan;

3. Adanya kerugian yang diderita;

4. Adanya hubungan kausalitas antara kesalahan dan kerugian.

Jika unsur tersebut dihubungkan dengan kasus mengenai tindakan pegawai Bank Mega mengenai transaksi simpanan deposito berjangka yang tidak tercatat pada sistem perbankan telah memenuhi ke 4 (empat) unsur diatas :

1. Adanya perbuatan yaitu perjanjian deposito berjangka diantara bank dan nasabah yang memberikan prinsip kepercayaan atas dana yang disimpan tersebut aman dan mempunyai kemampuan untuk dananya kembali apabila dibutuhkan sesuai dengan perjanjian deposito berjangka. hubungan hukum antara bank dan nasabah berlandaskan pada perikatan.

2. Adanya unsur kesalahan yaitu pihak bank selaku pegawai yang menjabat sebagai Kepala Cabang Kyai Tamin Bank Mega dengan inisiatif sendiri datang kerumah nasabah untuk melakukan transaksi deposito berjangka dengan alasan bahwa nasabah tersebut statusnya sebagai nasabah prioritas. Padahal nasabah priotas maupun nasabah umum pada Bank Mega diperlakukan sama dan harus datang ke kantor cabang saat melakukan transaksi. Serta pegawai bank tersebut tidak mencatat transaksi simpanan dana deposito berjangka pada sistem perbankan yang sudah disediakan.

3. Adanya kerugian yang diderita yaitu dengan transaksi simpanan dana deposito berjangka yang tidak tercatat pada sistem perbankan menyebabkan bilyet deposito sebagai bukti kepemilikan deposito berjangka para deposan tidak bisa ditukar atau tidak berlaku. Hal tersebut menimbulkan kerugian pada nasabah deposito berjangka

4. Adanya hubungan kausalitas antara sebab akibat dari kesalahan yaitu terhadap pegawai bank yang melakukan transaksi simpanan dana deposito berjangka dengan nasabah tidak tercatat dalam sistem perbankan Bank Mega yang menyebabkan nasabah tidak bisa mencairkan deposito berjangka nya karena bilyet deposito tersebut tidak terdaftar dalam sistem. Akibatnya nasabah mengalami kerugian material sebesar dana yang disetorkan ke bank. 
5. Mengenai teori tanggung jawab menurut Abdul Kadir Muhammad dalam perbuatan melanggar hukum (tort liability) jika dihubungkan dengan kasus termasuk kedalam tanggung jawab akibat dari perbuatan melanggar hukum yang dilakukan dengan sengaja (intertional tort liability), tergugat harus sudah melakukan perbuatan tersebut sehingga merugikan penggugat atau mengetahui bahwa apa yang dilakukan tergugat akan mengakibatkan kerugian. Jadi atas tindakan yang dilakukan oleh kepala cabang Bank Mega dilakukan dengan sengaja dalam hal tidak mencatat transaksi simpanan deposito berjangka milik nasabah. Karena kepala cabang atau pegawai bank tersebut sudah melakukan suatu perbuatan yang tidak beritikad baik.

Transaksi deposito berjangka yang tidak tercatat dalam sistem perbankan merupakan perbuatan melawan hukum yang dilakukan oleh pegawai bank menyebabkan kerugian pada nasabah. Adanya pasal 1365 KUHPerdata mewajibkan pegawai bank untuk tanggung jawab dalam hal mengganti kerugian atas simpanan dana deposito berjangka yang tidak tercatat yang disebabkan atas kesalahannya.

\section{Perlindungan Hukum Bagi Nasabah Terhadap Simpanan Deposito Berjangka Yang Tidak Tercatat Menurut Undang-Undang Nomor 10 Tahun 1998 tentang Perbankan.}

Setiap nasabah bank pada khususnya, diberikan perlindungan hukum untuk melindungi kepentingan nasabah tersebut dalam kapasitas sebagai subjek hukum yang melakukan tindakan hukum. Dalam analisa penulis selanjutnya, perlindungan hukum yang diberikan kepada nasabah digolongkan menjadi tiga (3), yaitu perlindungan hukum bagi nasabah melalui kebijakan bank, perlindungan hukum bagi nasabah berdasarkan Undang-Undang Nomor 10 Tahun 1998 tentang Perbankan, dan perlindungan hukum bagi nasabah berdasarkan Undang-Undang Nomor 8 Tahun 1999 tentang Perlindungan Konsumen.

Perlindungan nasabah menurut Undang-Undang Nomor 10 Tahun 1998 tentang Perbankan nyatanya kurang begitu mutlak. Karena sebagian besar pasal-pasal hanya berkonsentrasi pada aspek kepentingan perlindungan bank. Serta hanya menjelaskan mengenai cara pengawasan dan pembinaan bank yang efektif dan menghindarkan bank terjadinya kebangkrutan.

Sehingga kedudukan perlindungan hukum nasabah pada Undang-Undang tentang Perbankan pun menjadi lemah. Jadi diperlukannya undang-undang pendukung lainnya, seperti Undang-Undang Nomor 8 Tahun 1999 tentang Perlindungan Konsumen serta Peraturan Otoritas Jasa Keuangan Nomor 1/POJK.07/2013 tentang Perlindungan Konsumen Sektor Jasa Keuangan.

Menurut Pasal 1 ayat 1 Undang-Undang Nomor 8 Tahun 1999 tentang Perlindungan Konsumen, penjelasan mengenai perlindungan konsumen adalah segala upaya yang menjamin adanya kepastian hukum untuk memberi perlindungan kepada konsumen. Dalam hal tersebut sesuai dengan Misi Otoritas Jasa Keuangan yaitu:

1. Melaksanakan terselenggaranya seluruh kegiatan di dalam sector jasa keuangan secara teratur, adil, transparan, dan akuntabel;

2. Menghasilkan system keuangan yang tumbuh secara berkelanjutan dan stabil;

3. Menjaga kepentingan konsumen dan masyarakat.

Dengan keterangan diatas dapat disimpulkan bahwa dengan adanya OJK tersebut bertujuan untuk mewujudkan system keuangan yang tumbuh secara stabil dan berkelanjutan, juga dapat melindungi kepentingan konsumen dan masyarakat. Perlindungan konsumen menjadi salah satu dari Otoritas Jasa Keuangan untuk melakukan pengawasan.

Untuk mewujudkan pelaksanaan perlindungan hukum nasabah terhadap simpanan deposito berjangka yang tidak tercatat, dalam hal ini Hermansyah membagi menjadi 2 macam, yaitu perlindungan hukum secara tidak langsung dan perlindungan hukum secara langsung.

\section{Perlindungan Tidak Langsung}

Perlindungan secara tidak langsung oleh dunia perbankan terhadap kepentingan nasabah penyimpan dana adalah suatu perlindungan hukum yang diberikan kepada nasabah penyimpan dana terhadap segala resiko kerugian yang timbul dari suatu kebijaksanaan atau timbul dari kegiatan usaha yang dilakukan oleh bank. Hal ini adalah suatu upaya dan tindakan pencegahan 
yang bersifat internal oleh bank yang bersangkutan dengan melalui hal-hal yang dikemukakan. Salah satu upaya nya sesuai dengan Pasal 29 ayat 2 Undang-Undang Nomor 10 Tentang Perbankan yang mengatakan bahwa "Bank wajib memelihara tingkat kesehatan bank sesuai dengan ketentuan kecukupan modal, kualitas asset, kualitas manajemen, likuiditas, rentabilitas, solvabilitas, dan aspek lain yang beruhubungan dengan usaha bank, dan wajib melakukan kegiatan usaha sesuai dengan prinsip kehati-hatian."

Pada kasus simpanan dana deposito berjangka yang tidak tercatat pada sistem perbankan secara resmi oleh kepala cabang bank atau pegawai Bank Mega tersebut yaitu sebuah pelanggaran. Menurut Undang-Undang Perbankan dalam melakukan kegiatan usaha harus sesuai dengan prinsip kehati-hatian. Dalam hal ini, Pasal 25 Peraturan POJK Nomor: 1/POJK.07/2013 menyebutkan bahwa Pelaku Usaha Jasa Keuangan wajib menjaga keamanan simpanan, dana, atau aset konsumen yang berada dalam tanggung jawab Pelaku Usaha Jasa Keuangan.

Tindakan ini juga yang harus dilaksanakan oleh pihak bank terkait dengan tindakan pegawai bank yang menyebabkan kerugian demi melindungi nasabah terdapat dalam Pasal 30 huruf b Peraturan OJK Nomor 1 / POJK. 07 / 2013, yaitu pelaku usaha jasa keuangan wajib mencegah pengurus, pengawas, dan pegawainya dari perilaku menyalahgunakan kewenangan, kesempatan, sarana yang ada padanya karena jabatan atau kedudukannya yang dapat merugikan konsumen.

Hal tersebut merupakan perlindungan tidak langsung yang diberikan kepada nasabah penyimpan berupa pelaksanaan prinsip kehati-hatian, serta lembaga keuangan wajib menjaga keamanan simpanan. Maka dari itu bank wajib melaksanakan prinsip kehati-hatian dalam menjalankan kegiatan usahany. Serta selalu konsisten dalam melaksanakan peraturan perundang-undangan di bidang perbankan berdasarkan profesionalisme dan itikad baik.

\section{Perlindungan Langsung}

Suatu perlindungan yang diberikan kepada nasabah penyimpan secara langsung terhadap kemungkinan timbulnya resiko kerugian dari kegiatan usaha yang dilakukan oleh bank. Dengan adanya perlindungan ini maka dapat dilakukannya tuntutan perlindungan hukum yang harus diberikan kepada nasabah. Adanya kasus simpanan deposito berjangka yang tidak tercatat pada Bank Mega atas tindakan pegawai bank yang merugikan nasabah. Hal tersebut sesuai dengan Pasal 1365 KUHPerdata yaitu perbuatan melawan hukum bahwa setiap orang yang melakukan perbuatan melawan hukum itu mewajibkan untuk mengganti kerugian yang timbul dari kesalahannya tersebut.

Atas tindakan yang dilakukan oleh YA juga sebagai Kepala Cabang Bank Mega Cabang Kyai Tamin sudah seharusnya nasabah mendapat perlindungan hukum dalam bentuk tanggung jawab atas dasar kerugian yang diderita oleh nasabah. Karena menurut Pasal 29 Peraturan POJK Nomor: 1/POJK.07/2013 tentang Perlindungan Konsumen Sektor Jasa Keuangan yang menyebutkan Pelaku usaha jasa keuangan wajib bertanggung jawab atas kerugian konsumen yang timbul akibat kesalahan dan/atau kelalaian, pengurus, pegawai pelaku usaha jasa keuangan dan/atau pihak ketiga yang bekerja untuk kepentingan pelaku usaha jasa keuangan.

Mengenai kemungkinan timbulnya resiko kerugian merupakan penyediaan informasi untuk memudahkan nasabah mendapatkan informasi mengenai kegiatan usaha dan kondisi bank menjadi lebih terbuka serta terwujudnya transparansi perbankan. Mengenai simpanan deposito berjangka yang tidak tercatat bank tidak menerapkan adanya penyediaan informasi yang sudah seharusnya dilakukan oleh bank. Seperti pada halnya Pasal 29 ayat (3) Undang-Undang Perbankan bahwa bank wajib menempuh cara-cara yang tidak merugikan bank dan kepentingan nasabah yang mempercayakan dananya kepada bank. Hal tersebut berhubungan dengan bank yang mewajibkan untuk memberikan informasi terkait dengan adanya transaksi nasabah yang dilakukan oleh bank. Karena dalam menjalankan usaha bank harus menempuh cara-cara yang tidak merugikan bank dan kepentingan nasabah, maka bank harus tunduk dalam melaksanakan peraturan perundang-undangan dalam menjalankan kegiatan perbankan. Hal tersebut merupakan suatu perlindungan hukum yang diberikan oleh bank terhadap nasabah.

\section{Kesimpulan}


Berdasarkan pembahasan dalam penelitian ini, peneliti menyimpulkan beberapa hasil penelitian sebagai berikut:

1. Bentuk tanggung jawab bank terhadap nasabah atas transaksi simpanan deposito berjangka yang tidak tercatat pada sistem perbankan secara resmi ialah pertanggung jawabannya berdasarkan teori pertanggung jawaban berdasarkan kesalahan. Hal tersebut sesuai dengan pasal 1365 KUHPerdata yaitu pegawai bank tersebut telah melakukan perbuatan melanggar hukum dan wajib untuk mengganti kerugian sebesar kerugian nasabah yang timbul dari kesalahaannya.

2. Perlindungan hukum yang dapat diterima nasabah bank dalam hal transaksi simpanan deposito berjangka yang tidak tercatat dalam sistem perbankan secara resmi oleh pegawai Bank Mega. Maka nasabah berhak mendapatkan perlindungan hukum langsung yang diatur pada Pasal 29 ayat (3) Undang-Undang Perbankan bahwa bank wajib menempuh cara-cara yang tidak merugikan bank dan kepentingan nasabah yang mempercayakan dananya kepada bank. Serta pelindungan tidak langsung menurut Pasal 29 ayat 2 Undang-Undang Nomor 10 Tahun 1998 tentang Perbankan yaitu memberikan perlindungan hukum kepada nasabah penyimpan berupa pelaksanaan prinsip kehati-hatian, serta lembaga keuangan wajib menjaga keamanan simpanan

\section{Daftar Pustaka}

[1] Anindya Febriana (dkk), "Perlindungan Hukum Terhadap Deposan Dalam Pelaksanaan Simpanan Deposito Terkait Dengan Prinsip Kehati-hatian Bank", Diponegoro Law Journal, Vol.5, No.3, Tahun 2016

[2] Hermansyah, Hukum Perbankan Nasional Indonesia, Kencana, Jakarta, 2008

[3] Praevilia M. L. Rotinsulu, "Aspek Hukum Deposito Berjangka Dalam Praktek Pada Bank Pemerintah Menurut UU No. 10 Tahun 1998 Tentang Perubahan Atas UU No. 7 Tahun 1992 Tentang Perbankan”, Lex Crimen, Vol. VI, No.1, Jan-Feb 2017.

[4] Munir Fuady, Konsep Hukum Perdata, Cetakan Pertama, PT Raja Grafindo Persada, Jakarta, 2014

[5] Salim HS dan Erlies Septiana Nurbani, Penerapan Teori Hukum Pada Penelitian Disertasi dan Tesis, Buku Kedua, Rajawali Pres, Jakarta

[6] Shidarta, Hukum Perlindungan Konsumen Indonesia, PT Grasindo, Jakarta, 2006.

[7] Setiono, Rule Of Law (Supremasi Hukum), Magister Ilmu Hukum Pasca Sarjana Universitas Sebelas Maret, Surakarta, 2004

[8] Sentosa Sembiring, Sinopsis Hukum Perbankan, Citra Aditya Bakti, Bandung, 1993.

[9] Hermansyah, Hukum Perbankan Nasional Indonesia, Kencana, Jakarta, 2006.

[10] Visi Misi, terdapat dalam http://www.ojk.go.id. Diakses pada tanggal 07 Mei 2018 Pukul 19.00 WIB 